\title{
Resiliensi Perempuan Korban Kekerasan Seksual dalam Metropop Scars and Other Beautiful Things karya Winna Efendi
}

\author{
Tania Intan ${ }^{1}$, Ferli Hasanah ${ }^{2}$ \\ Departemen Susastra dan Kajian Budaya, Universitas Padjadjaran \\ tania.intan@unpad.ac.id ${ }^{1}$, ferli.hasanah@unpad.ac.id ${ }^{2}$
}

DOI: https://doi.org/10.32528/bb.v6i2.5757

First received: 14-08-2021 Final proof received: 30-09-2021

\begin{abstract}
ABSTRAK
Penelitian ini bertujuan untuk menunjukkan resiliensi perempuan sebagai korban kekerasan seksual di dalam novel Scars and other beautiful things (2020) karya Winna Efendi. Metode yang diterapkan untuk penelitian ini adalah deskriptif kualitatif dengan pendekatan kritik sastra feminis. Data yang terdiri dari kata, frasa, dan kalimat di dalam novel tersebut dikumpulkan dengan teknik simak catat setelah melalui pembacaan tertutup. Data selanjutnya dikategorisasi, diinterpretasi, dan dikaji dengan teori-teori yang relevan dengan permasalahan kekerasan seksual dan resiliensi perempuan. Penelitian ini memperlihatkan bahwa kekerasan seksual merupakan bentuk ekspresi maskulinitas dan penegasan kekuasaan. Kekerasan seksual juga berkaitan dengan stereotip perempuan sebagai korban yang disalahkan karena dianggap berpakaian terbuka sehingga mengundang hasrat laki-laki. Tokoh Harper pun memperlihatkan resiliensi untuk keluar dari situasi traumatis yang tidak menguntungkannya dengan bantuan dari sistem pendukungnya yaitu keluarga, sahabat, dan pacarnya. Melalui novel Scars, terungkap kritik pengarang mengenai kasus kekerasan seksual yang kerap menimpa perempuan (maupun laki-laki). Kenyataan memperlihatkan bahwa pelakunya sering tidak mendapatkan hukuman yang adil, dan yang sering terjadi, korban yang seharusnya dilindungi dan mendapatkan hak konseling cenderung dikriminalisasi.
\end{abstract}

\section{Kata kunci: resiliensi; perempuan; kekerasan seksual; metropop}

\footnotetext{
ABSTRACT

This study aims to show the resilience of women as victims of sexual violence in the novel Scars and other beautiful things (2020) by Winna Efendi. The method applied for this research is descriptive qualitative with a feminist literary criticism approach. The data consisting of words, phrases, and sentences in the novel were collected using a note-taking technique after going through closed reading. The data is then categorized, interpreted, and studied with theories relevant to the problem of sexual violence and women's resilience. The results of this study show
} 
that This study reveals that sexual violence is a form of the expression of masculinity and affirmation of power. Sexual violence is also related to stereotypes about women as victims who are actually blamed because they are considered to be dressed openly that invites male desires. Harper's character also shows resilience to get out of a traumatic situation that is very unfavorable to him, with the help of his support system, namely family, friends, and his girlfriend. Through the novel Scars, the author's criticism is revealed about cases of sexual violence that often afflict women (as well as men). The reality shows that the perpetrators often do not get the punishment they deserve and what often happens is that victims who should be protected and get counseling rights are actually criminalized.

\section{Keywords: resilience; woman; sexual violence; metropop}

\section{PENDAHULUAN}

Kekerasan pada perempuan merupakan isu yang telah menjadi fokus perhatian dan dikritik oleh para feminis sejak lama. Menurut Garcia-Moreno, kekerasan memiliki konsekuensi terhadap kesehatan mental perempuan (Appleton, 2018). Risiko tersebut sejalan dengan pandangan CEDAW (Convention on the Elimination of all Forms of Discrimination Against Women), bahwa kekerasan, apa pun bentuknya, merupakan pelanggaran terhadap hak-hak asasi manusia dan kemanusiaan perempuan (Eddyono, 2014).

Perempuan memang lebih kerap menjadi korban kekerasan dibandingkan dengan laki-laki karena pada dasarnya, kekerasan terjadi akibat ketimpangan gender yang mewujud pada penggunaan kekuasaan, ketidaksetaraan, dan dominasi (Sari, 2017). Oleh karena itu, dalam wacana gender realitas hasrat menguasai makhluk lainnya hampir selalu diatribusikan pada laki-laki. Konstruksi budaya inilah yang menempatkan perempuan sebagai subordinat dan pihak yang lemah, yang memantaskan mereka menjadi 'korban'. Sebagaimana dinyatakan Humm (2007: 486) yang merangkum pemikiran para feminis, bahwa kekerasan dilakukan untuk mengontrol perempuan dalam aturan dan perilaku yang diperuntukkan bagi mereka termasuk seksualitas dan peran reproduksi mereka.

Fenomena kekerasan yang umumnya dilakukan laki-laki pada perempuan ini dapat dikaitkan dengan wacana maskulinitas yang menunjukkan bahwa kekerasan merupakan hal yang dipelajari laki-laki untuk mengekspresikan maskulinitas dalam interaksinya dengan perempuan, anak, atau laki-laki lain (Figes, 1986). Milestone (2012) menjelaskan bahwa maskulinitas merupakan ciri laki-laki yang "presented as strong, active, powerful, authoritative, hard, aggressive, violent, competitive and rational, and lacking sensitive and emotions". Kekuasaan patriarki, menurut Winarno (2003), memang memberikan ruang bagi laki-laki untuk memperlakukan perempuan atau laki-laki lain sebagai pihak subordinat, sesuai dengan kehendak mereka yang memiliki privilege dalam lingkungan sosial mereka, seperti kekuatan fisik, harta, pendidikan, jabatan, dan keturunan. Pihak yang memiliki kekuasaan yang dibiarkan bebas dan tanpa pengawasan seperti itu berpotensi melakukan kekerasan pada pihak yang didominasi, seperti dijelaskan 
Lardellier bahwa kekerasan selalu didasari oleh prinsip pemaksaan pada pihak lain dengan atau tanpa persetujuan (Haryatmoko, 2010).

Dalam pandangan Bhasin yang dikutip Kurnianto (2016: 89) sistem patriarki menjadikan gagasan tersebut sebagai ideologi bahwa laki-laki lebih superior dibandingkan perempuan, sehingga perempuan sudah seharusnya dikontrol dan dijadikan bagian dari properti laki-laki. Dalam kultur patriarki, perempuan didefinisikan sebagai makhluk yang secara seksual pasif dan reseptif. Pandangan seksis tersebut dianggap logis untuk menafsirkan kepasifan perempuan sebagai ekspresi minat seksual mereka (Humm, 2007: 389).

Kekerasan seksual dapat menimbulkan trauma mendalam pada korbannya. Trauma sendiri dijelaskan Caruth dalam Intan dan Gumilar (2020: 11) sebagai situasi yang terjadi pada seseorang yang mengalami peristiwa yang membuatnya terguncang serta sulit menerima kejadian buruk itu sebagai bagian dari hidupnya. Namun, perempuan tidak selalu bersikap pasif dan menyerah karena ada kesadaran dari dalam dirinya untuk melakukan upaya bangkit dari keterpurukan, yang disebut Siebert (2005) sebagai 'resiliensi'. Resiliensi secara luas didefinisikan Masten yang dikutip Zahra (2021: 121) sebagai kapasitas sistem dinamis untuk berhasil beradaptasi dengan gangguan yang mengancam fungsi, viabilitas, atau perkembangan. Sementara itu, Ungar (2019) menjelaskan bahwa resiliensi berkaitan dengan kapasitas sistem bio-psiko-sosial yang mengarahkan sumber daya tertentu untuk dapat mempertahankan fungsi positif selama kondisi sulit. Sameroff dkk. (2003) berargumentasi bahwa ada dua jenis penilaian yang menjadi syarat dari resiliensi, yaitu adanya faktor risiko atau ancaman, dan adanya kriteria mengenai kualitas hasil yang dianggal baik 'doing okay'.

Menurut Marlia, melalui Intan dan Gumilar (2020: 16), meskipun menghadapi permasalahan berat dalam hidupnya, banyak perempuan yang mampu untuk mempertahankan hidup dan menyesuaikan diri dengan keadaannya. Resiliensi perempuan korban kekerasan seksual merupakan tema yang ditemukan dalam novel bergenre metropop dengan judul Scars and Other Beautiful Things (2020) karya Winna Efendi. Pengarang perempuan yang aktif menulis sejak tahun 2007 ini menghasilkan sejumlah karya yang beberapa di antaranya sukses diadaptasi ke layar lebar, seperti Refrain, Remember When, dan Melbourne: Rewind. Novel Scars and Other Beautiful Things, yang selanjutnya diacu sebagai Scars, dipilih sebagai objek formal kajian karena merupakan buku terbaru dari penulis tersebut setelah absen selama empat tahun. Novel tersebut terinspirasi dari kisah nyata mengenai kasus kekerasan seksual oleh mahasiswa Universitas Stanford pada seorang remaja perempuan mabuk (Hd, 2016). Di kemudian hari, terungkap bahwa korban bernama Chanel Miller dan pelakunya adalah Brock Allen Tunner, seorang atlet renang kampus yang berasal dari keluarga terpandang.

Tema kekerasan pada perempuan dalam karya fiksi juga bukan merupakan hal yang eksklusif sebagaimana telah dibahas dalam sejumlah penelitian, seperti oleh Kanserina (2011), Fitri (2018), Prasetyo dan Haryadi (2017), Hardiyanto (2008), Astuti (2021), dan Mayroh (2019). Banyaknya kajian mengenai isu tersebut memperlihatkan bahwa kekerasan pada perempuan sangat relevan dengan kehidupan dan merupakan hal yang 
menarik perhatian banyak orang, karena belum ada penyelesaian yang tuntas dan efektif untuk menangkalnya.

Kajian tentang resiliensi perempuan sendiri telah dilakukan di antaranya oleh Intan dan Gumilar (2020) pada novel Perempuan Bersampur Merah karya Intan Andaru yang mengungkap bahwa stigma dan pandangan negatif masyarakat pada para tokoh perempuan dilawan melalui perilaku resilien mereka. Sementara itu, Werdiningsih (2016) yang mengkaji novel Kinanti karya Margareth Widhy Pratiwi, menemukan bahwa kelemahan biologis perempuan dimanfaatkan oleh pelaku kekerasan, namun pada akhirnya tokoh perempuan berusaha untuk melawan dengan keterbatasannya.

Namun, dari penelusuran yang telah dilakukan, kajian terhadap resiliensi perempuan korban kekerasan seksual dalam karya fiksi belum banyak dilakukan, sehingga penelitian terhadap isu tersebut pun menjadi bernilai dan penting sebagai landasan untuk analisis serupa. Kajian akademis terhadap novel setebal 296 halaman tersebut pun belum ditemukan, karena Scars baru diterbitkan pada bulan Mei tahun 2020. Untuk membatasi wilayah pembahasan, maka tujuan yang dirumuskan untuk penelitian ini adalah menunjukkan resiliensi perempuan sebagai korban kekerasan seksual di dalam novel Scars and other beautiful things karya Winna Efendi.

\section{METODE PENELITIAN}

Metode yang digunakan dalam penelitian ini adalah deskriptif kualitatif. Penelitian dilakukan dengan cara mendeskripsikan dan menganalisis fenomena, peristiwa, aktivitas sosial, sikap, kepercayaan, persepsi, dan pemikiran tokoh secara individual maupun kelompok (Sunarti, tanpa tahun: 3).

Penelitian ini menggunakan perspektif kritik sastra feminis. Pemikiran feminis selalu berusaha melihat permasalahan mengenai adanya relasi kuasa yang timpang, baik individu maupun kelompok, dalam masyarakat sosial yang cenderung memberikan kuasa lebih besar kepada laki-laki untuk menentukan dan mengambil keputusan. Dengan dilakukannya penelitian feminis, ketimpangan relasi kuasa antara laki-laki dan perempuan akan dapat digambarkan, dianalisis, dan 'disuarakan' dengan lantang (WRI, 2011). Budianta, dalam Yulianto (2018: 4), menjelaskan bahwa pendekatan kritik sastra feminis merupakan studi ideologis terhadap cara pandang yang mengabaikan permasalahan ketimpangan dan ketidakadilan dalam pemberian peran dan identitas sosial berdasarkan perbedaan jenis kelamin. Sementara itu, Priyatna dan Budhyono (2020: 192) menjelaskan bahwa kritik sastra feminis menganalisis teks berdasarkan unsur-unsur konstruktifnya seperti "kritik sastra pada umumnya". Yang berbeda, dalam kritik sastra feminis, kajian dihidupkan oleh kesadaran tentang adanya ketimpangan di antara apa yang ditandai sebagai perempuan dan laki-laki dengan hasrat untuk melakukan resistensi menghadapi ketidaksetaraan tersebut.

\section{PEMBAHASAN}

Untuk mendapatkan pemahaman yang utuh tentang cerita, permasalahan kekerasan seksual, dan resiliensi korban, pembahasan dilakukan secara bertahap. Bagian ini terdiri dari tiga hal, yaitu: (1) narasi tentang stigma dan trauma perempuan korban 
kekerasan seksual, (2) kekerasan seksual dalam tinjauan kritik sastra feminis, dan (3) resiliensi perempuan korban kekerasan seksual.

\section{Novel Scars: Kisah tentang Stigma dan Trauma Perempuan Korban Kekerasan Seksual}

Novel tersebut terdiri dari empat puluh bab, yang masing-masing diberi judul sesuai dengan topik yang dibahas, mulai dari tempat seperti Tomales High School dan Santa Rosa, tokoh seperti Adam, Miss Yarley, dan Jordan, serta hal lainnya, yaitu The Rest of The World dan Hurt. Bab-bab awal dan pertengahan mengisahkan para tokoh, tempat, benda, dan kejadian-kejadian di sekitar tokoh utama. Sementara itu, dalam babbab terakhir dikisahkan tentang Scott Gideon, Harper, dan ditutup dengan sebuah epilog. Penyusunan bab seperti ini menyiratkan bahwa setelah sekian lama menghindar, tokoh perempuan itu mulai dapat menerima kejadian pemerkosaan sebagai luka yang dapat mengering dan disembuhkan. Ia tidak lagi segan membicarakannya.

Novel tersebut dibuka dengan penyajian berita harian Bodega Bay Daily yang mengisahkan kejadian pemerkosaan pada Harper Simmons dengan judul "Pesta di Santa Rosa Berujung Nahas: Serangan Seksual atau Kencan Semalam yang Berakhir Buruk?" (hal. 7-8). Berita lain dari harian tersebut muncul di pertengahan novel dengan judul "Pelaku Pemerkosaan Kampus Santa Rosa akan Dibebaskan" (hal. 208-209). Bila berita pertama yang diletakkan pada awal novel mengawali cerita tentang peristiwa kekerasan seksual dan masih menunjukkan nada keraguan atas peristiwa pemerkosaan yang dialami remaja perempuan itu apakah "serangan seksual" atau hanya sekedar "kencan semalam yang berakhir buruk", maka berita kedua memperlihatkan adanya afirmasi dan keyakinan publik bahwa kejadian tersebut benar-benar sebuah 'pemerkosaan' dan bukan hubungan konsensual.

Dari sudut pandang orang pertama, novel tersebut dinarasikan oleh tokoh-pencerita Harper Simmons, siswi Tommales High School yang berusaha mengalahkan trauma yang dideritanya akibat kasus pemerkosaan yang terjadi pada sebuah pesta di awal musim panas. Sebagai narator, ia mengisahkan berbagai kesulitan yang dihadapi diri dan keluarganya setelah kejadian itu. Scars dikisahkan dengan alur maju dengan sisipan adegan-adegan flashback dan ditutup dengan kondisi penerimaan diri akibat peristiwa yang membuat pikiran tokoh perempuan itu 'tidak sama lagi'. Latar cerita yang digunakan adalah kota Bodega Bay dan New York di Amerika. Penggunaan setting luar negeri ini dinyatakan Nurhadi (tanpa tahun) dapat berkaitan dengan ruang gerak pengarang Indonesia, termasuk Winna Efendi, sebagai bagian dari warga dunia.

Harper Simmons menampilkan dirinya sebagai gadis berumur 17 tahun yang cerdas. Ia merupakan siswi SMA dengan prestasi gemilang, ceria, aktif dalam klub debat, memenangkan banyak turnamen, memiliki banyak teman dan keluarga yang selalu mendukungnya. Adam, pacarnya, juga sangat menyayanginya. Namun, sejak kejadian pemerkosaan menimpanya, remaja perempuan itu berubah, ia sangat terguncang dan mentalnya seperti terganggu. 
[...] fakta tersebut sama sekali tak menyusutkan rasa cemasku. Aku menahan desakan untuk mengecek kolong ranjang dan memastikan tidak ada bayangbayang aneh yang menghuni ruang gelap di bawah sana, layaknya anak kecil yang masih mengompol di celana akibat cerita horor ala perkemahan. (Efendi, 2020: 11-12)

Dalam narasi yang disampaikan Harper untuk melukiskan kejadian perkosaan pada malam pesta menjelang musim panas itu, ia menggunakan kosa kata yang menggambarkan kondisi dirinya, dengan adjektiva seperti "gelap", "samar-samar", "buram", "membingungkan", "basah", "terlepas", "terpelanting”, dan "tak berdaya" (hal. 10). Gambaran kondisi yang berkonotasi ketidaknyamanan tersebut juga diperkuat dengan penggunaan sejumlah kata kerja yang menunjukkan perlawanan yang sia-sia, seperti "membabi buta", "mencakar", "menggigit”, "mencengkeram”, “menghantam”, "mengimpit", "merintih", "berteriak", dan "tercekat" (hal. 10) yang merujuk pada perilaku kekerasan seksual yang dialami remaja perempuan itu. Situasi ini membuktikan gagasan Garcia-Moreno melalui Appleton (2018), bahwa kekerasan memiliki konsekuensi pada kesehatan mental perempuan sebagaimana dipaparkan di sepanjang cerita. Gejala gangguan mental akibat pemerkosaan yang disebutkan dalam novel Scars di antaranya: mimpi buruk dan insomnia (hal. 64), perasaan dibuntuti (hal. 37), ketakutan (hal. 10, 92), perasaan mudah terkejut (hal. 37, 125), perasaan bersalah (hal. 52, 63, 113), dan perilaku yang cenderung menyendiri (hal. 68) sehingga merusak hubungannya dengan orang-orang terdekat (hal. 60, 116).

Setelah kepulangan mereka, aku mengunci diri di kamar mandi, membiarkan air panas mengucur hingga kulitku terasa terbakar. Kotor. Aku merasa kotor, seberapa banyak pun aku membasuh diri dan menghapus jejak pria itu dari tubuhku. [...] Tanpa pikir panjang aku meraih benda tajam terdekat dan mulai membabi buta memotong rambutku. (Efendi, 2020: 138-139)

Tendensi merusak diri juga ditunjukkan gadis itu melalui pengabaian atas tugastugas sekolah dan membolos. Ia juga mengambil keputusan untuk meninggalkan klub debat yang sebelumnya menjadi kegiatan ekstrakurikuler yang paling disukainya (hal. 30). Di saat sedang takut dan gelisah, sebagai bentuk mekanisme pertahanan diri Harper juga selalu menekan telapak tangannya sendiri dengan kuku-kuku jari hingga luka dan berdarah (hal. 14). Dalam novel, ia beberapa kali menarasikan isi hatinya berupa monolog karena sulit menyatakan perasaannya. Sebagai korban, ia merasa lemah dan tidak berhak berbicara lagi karena menurutnya tidak ada orang yang benar-benar mendengarkan.

Harper Simmons adalah korban -itu kan, faktanya? Satu-satunya kata yang mereka gunakan untukku sepanjang proses pengadilan berlangsung. Korban. Korban. Korban. Seharusnya label itu distempel besar-besar di keningku. Bagi mereka, aku tak lebih dari korban yang karena kesalahannya sendiri telah membiarkan hal buruk terjadi padanya. Lambat laun aku bahkan membiarkan diriku sendiri memercayainya. (Efendi, 2020: 188) 
Tekanan yang dialami Harper tidak hanya berasal dari dirinya sendiri yang masih dibayang-bayangi peristiwa pemerkosaan yang dialaminya, melainkan juga dari luar yang membuat remaja perempuan itu semakin gamang dan tidak percaya diri. "Lambat laun aku bahkan membiarkan diriku sendiri mempercayainya". Pandangan masyarakat umum yang diterima oleh Harper memang sangat beragam. Sebagian menyalahkannya sendiri yang mabuk dan mau saja diajak berhubungan seksual di area pembuangan sampah oleh laki-laki yang tidak dikenalnya, yang berarti "karena kesalahannya sendiri telah membiarkan hal buruk terjadi padanya" seperti terungkap dalam kutipan tersebut. Sebagian masyarakat lainnya memandang kasihan dan menunjukkan sikap seolah-olah turut prihatin yang, menurut Harper, terasa berlebihan dan justru membuatnya semakin terpuruk.

Asumsi. Tuduhan. Iba. Pandangan itu mengikutiku ke mana-mana, dan aku tahu jika memejamkan mata sekalipun, aku tetap dapat merasakannya. Kutegakkan badan dan berjalan secepat mungkin, sampai tiba-tiba Emma Harding muncul entah dari mana dengan kamera di tangannya. Flash!

Jepretan menyilaukan itu mengacaukan konsentrasiku untuk sementara. (Efendi, 2020: 14)

Trauma yang dialami Harper juga membuat kehidupannya berubah menjadi menakutkan dan membuatnya harus selalu waspada. Kutipan tersebut memperlihatkan bagaimana sorotan publik yang ditujukan pada korban kekerasan seksual terasa sangat mengganggu. Kemalangan Harper justru menarik perhatian tokoh Emma Harding yang berprofesi sebagai wartawan sekolah. Emma bahkan tidak segan mendesak temannya itu untuk melakukan wawancara eksklusif untuk majalah sekolah mereka. Situasi ini dapat dipahami sebagaimana diungkapkan Caldas-Coulthard yang dikutip Priyatna (2018: 300) bahwa "seks adalah salah satu produk yang paling menarik untuk dijual".

Bayangan tentang peristiwa pemerkosaan membuat Harper mengalami trauma dan sulit berhubungan dengan kekasihnya. Berkali-kali ia seperti melihat sosok yang mirip dengan pemerkosanya di jalan. "Posturnya atletis, rambutnya yang pirang sebagian besar tertutupi topi baseball merah" (hal. 133). Perasaan selalu dikuntit atau diawasi oleh seseorang pun merupakan gangguan mental yang dialami remaja perempuan itu. Selain harus mengatasi situasi tersebut, Harper pun menjadi pihak yang mendapatkan penilaian tidak adil karena dituding menyepakati terjadinya pemerkosaan atas dirinya. Tidak adanya penolakan yang berarti dan 'pakaian terbuka' dianggap sebagai bagian dari konsensus atas terjadinya hubungan seksual di antara korban dan pelaku. Tidak ada unsur paksaan dalam apa yang terjadi malam itu. Dia mengatakan ya saat aku mengajaknya berdansa, ya pada ajakanku untuk meninggalkan pesta, ya ketika aku bertanya apa aku bisa menyentuhnya (hal. 22). Trauma Harper juga muncul saat ia tidak sengaja mendengar lagu yang dimainkan di malam saat ia diperkosa.

Satu lagu aneh yang diputar itu berakhir, diikuti lagu lain yang familier -tembang lama dari era enam puluhan yang sering kudengar di stasiun radio. Twisting, 
twisting. [...] Aku tak ingat melakukan apa. Karena selanjutnya yang kutahu, aku terbaring di tempat tidur rumah sakit dengan luka-luka di sekujur tubuhku, dan mereka yang mengatakan bahwa aku telah diperkosa. (Efendi, 2020: 134-135)

Dalam novel, Harper menarasikan isi hatinya berupa monolog karena ia sulit menyatakan perasaannya terkecuali pada terapisnya, Dokter Lewis, sebagaimana diperlihatkan dalam kutipan tersebut. Harper juga menarasikan bahwa yang menjadi 'korban' ulah Scott Gideon bukan hanya dirinya melainkan juga keluarganya. Ayahnya mengalami depresi, demikian pula dengan Avery yang selalu merasa bersalah karena meninggalkan saudara kembarnya itu di pesta dan menyebabkan Harper mengalami pemerkosaan.

Namun, realita memperlihatkan bahwa, alih-alih mendapat dukungan dan perlindungan, perempuan korban kekerasan seksual justru kerap mendapatkan cemoohan dan tudingan-tudingan sebagaimana ditunjukkan di dalam novel Scars. Sejumlah stigma yang diterima oleh Harper di antaranya "jalang" (hal. 211), "haus perhatian", "pembohong", "penggoda pacar orang" (hal. 96), "korban gadungan", dan "murahan" (hal. 16), "memutarbalikkan fakta" dan "mengaku diperkosa" (hal. 98), dan "cuma caricari sensasi" (hal. 52). Stigma dan ejekan juga dilekatkan padanya karena kondisi psikologisnya yang belum stabil setelah kejadian itu, seperti: "tidak sesuai untuk kesehatan mentalmu?", "penderita trauma" (hal. 44), atau "apa kalian mencium bau keputusasaan di sekitar sini?" (hal. 96). Hampir seluruh celaan dan tuduhan tersebut dibuat dan disebarkan oleh Kimberly dan teman-temannya.

Sebagai tokoh antagonis, Kimberly memang digambarkan secara konsisten gemar menjatuhkan perempuan lain, mulai dari bergunjing, mengejek, menghakimi, hingga memandang sinis mereka yang dianggap tidak berada dalam status yang sama. Konstruksi sosial yang melekat pada perempuan yang dalam konstruksi sosial seperti lebih sensitif, memiliki belas kasih, dan penyayang pun ternyata tidak berlaku pada tokoh tersebut. Hal ini mengimplikasikan bahwa tidak seluruh perempuan berempati terhadap kondisi yang dialami sesamanya sebagai korban kekerasan seksual. Sebaliknya, hujatan-hujatan yang dibuat perempuan ternyata dapat lebih pedas, jahat, dan berdampak melukai daripada laki-laki.

Dengan berbagai motif, kelompok perempuan yang direpresentasikan oleh Kimberly ini juga seperti berpihak pada pelaku pemerkosaan seperti yang terungkap dalam pernyataan "Gara-gara kau, hidup Scott Gideon sekarang berantakan" (hal. 96). Selain menyalahkan dan mencemooh Harper, Kimberly juga menunjukkan bahwa menurutnya, peristiwa pemerkosaan itu tidak nyata. "Apa mungkin kalau kejadian itu sekedar rekaan dalam imajinasimu? Atau, akibat penyesalan setelah kencan satu malam, kau memutarbalikkan fakta dan mengaku diperkosa?" (Efendi, 2020: 97-98). Situasi ini memperlihatkan sudut pandang Kimberly yang meragukan cerita tentang pemerkosaan. Pihak yang menjadi korban dalam situasi ini justru adalah laki-laki pelaku kekerasan seksual, dan tuntutan Harper di persidangan dianggap tidak berdasar sehingga "menghancurkan hidup seseorang" yang mengacu pada Scott Gideon. Tuduhan seperti itu memperlihatkan bahwa maskulinitas ditunjukkan sebagai hal yang secara alamiah 
bersifat agresif dan tidak selalu dapat dikendalikan. Sebaliknya, dalam kutipan tersebut femininitas ditunjukkan melalui sifat memelihara yang mencintai dan sabar sebagaimana ditunjukkan oleh ilustrasi "puluhan gadis yang rela menyembah kakinya tanpa paksaan." Situasi ini memperlihatkan superioritas laki-laki dan naturalisasi atas kekerasan yang dilakukan mereka. Dengan demikian, perlawanan yang dilakukan oleh Harper dinilai Kimberly sebagai sebuah kejahatan yang sesungguhnya.

Kurangnya keberpihakan publik pada perempuan korban kekerasan seksual juga diperlihatkan melalui peristiwa yang dialami Miranda Lee, tokoh perempuan lain yang pendiam dan pintar di sekolah Harper. Ia terpergok sedang memegang alat tes kehamilan dengan tanda positif di toilet. Alih-alih mendapat dukungan dan empati atas kondisinya, Miranda justru mengalami perisakan dan mendapat cemoohan dari teman-temannya. Kondisi ini menunjukkan bagaimana perempuan selalu diposisikan sebagai subordinat, seperti dijelaskan Lardellier melalui Haryatmoko (2010) bahwa pihak yang memiliki kekuasaan selalu dibiarkan bebas dan tanpa pengawasan sehingga berpotensi melakukan kekerasan.

Kalau sebelumnya dia nyaris tak kasatmata, sekarang orang-orang memperlakukannya layaknya wabah -atau lebih buruk lagi, sebuah target. [...]

Dia menyeberangi kafetaria dengan kepala tertunduk, tampak berusaha menghindari perhatian. Tiba-tiba seseorang menjengkat kakinya hingga terjatuh, dan susu kotak yang terbuka di tangannya tumpah membasahi seluruh pakaiannya. Mereka semua tertawa ... (Efendi, 2020: 226)

Tindakan perisakan terhadap Miranda dalam kutipan tersebut memperlihatkan bahwa perempuan rentan mengalami opresi, baik oleh laki-laki maupun sesama perempuan. Dari pembahasan ini, terungkap pula bahwa alih-alih memberikan perlindungan dan dukungan penuh pada korban kekerasan seksual yang sedang berjuang mengatasi trauma, sebagian orang justru melekatkan stigma buruk padanya sehingga proses pemulihan pun semakin sulit dilakukan. Untuk mendapatkan pemahaman yang lebih komprehensif mengenai novel Scars, pembahasan selanjutnya membincangkan kekerasan seksual dari tinjauan sastra feminis.

\section{Kekerasan Seksual [yang Dianggap] sebagai Ekspresi Maskulinitas}

Dari sudut pandang feminis, pemerkosaan merupakan tindakan dan institusi sosial yang melanggengkan dominasi patriarki yang didasari oleh kekerasan, bukan sekadar kejahatan kekerasan biasa (Humm, 2007: 388). Kaitan antara kekerasan seksual dan ketimpangan peran gender ini telah terlihat sejak halaman-halaman awal novel Scars yang menampilkan cara media setempat, Bodega Bay Daily, dalam menggambarkan korban, pelaku pemerkosa, dan peristiwa pemerkosaan. Korban yang tidak disebut namanya dideskripsikan dalam kolom surat kabar itu sebagai "seorang remaja perempuan berusia tujuh belas tahun", "kondisi tidak sadar", "tidak bergerak", "tidak responsif" (hal. 7), "darah', "korban', "dibawa ke rumah sakit dalam keadaan terluka", "tidak sadar", "murid tahun terakhir sekolah menengah" (hal. 8). Kelompok kata ini 
menampilkan identitas anonim atau kerap disebut 'Jane Doe' dalam konteks kriminal, serta situasi menyedihkan yang dialami oleh tokoh remaja perempuan, Harper Simmons. Perannya sebagai perempuan dan korban dikecilkan, sehingga subjektivitasnya pun menjadi sangat minimal dan seperti tidak penting.

Sebagai perempuan yang mengalami kekerasan seksual, Harper juga mengalami pembungkaman. Saat peristiwa itu terjadi, ia dilarang bersuara oleh si pemerkosa dengan pernyataan "Sshh, kau akan baik-baik saja", yang menunjukkan larangan sekaligus bujukan agar Harper tidak mengungkapkan penolakan. Intimidasi dan paksaan itu disebutkan Harper terus menerus muncul dan menghantui pikirannya (hal. 10, 21, 39). Dalam perspektif Gender Equality Index-Report (2013), pemerkosaan dan paksaan untuk berhubungan seksual seperti ini tidak lain merupakan ekspresi maskulinitas dan penegasan atas kekuasaannya. Dengan mengutip Brownmiller, Griffin, dan Dworkin, Humm (2007: 389) menjelaskan bahwa ideologi patriarki melegitimasi pemerkosaan dengan mendefinisikannya sebagai hal yang 'normal'. Bukan hanya perempuan dianggap sebagai objek seksual, melainkan juga laki-laki dianggap memiliki hasrat dan dorongan untuk melakukan relasi heteroseksual dengan orang yang diminatinya.

Sejurus kemudian, tangannya mencengkeram lenganku dan gerakan tiba-tiba itu membuatku terpelanting menghantam tanah. [...]

Jangan, hanya itu yang bisa kurintihkan.

Kali ini dia menunduk dan berbisik persis di samping telingaku. Napasnya bau alkohol, juga sesuatu yang masam. Suaranya lembut, kontras dengan apa yang sedang dia perbuat. Sshh ... kau kan baik-baik saja. (Efendi, 2020: 10)

Kutipan tersebut merupakan pengakuan Harper pada terapisnya. Ia marah karena tidak dapat membela diri, baik pada saat kejadian tersebut maupun setelahnya. Dalam pandangannya, pembungkaman bukan hanya dilakukan si pemerkosa melainkan juga oleh sebagian publik yang tidak senang saat ia menuntut Scott Gideon ke pengadilan. Akibat celaan mereka, remaja perempuan itu sempat menganggap dirinya tidak cukup kredibel untuk mengungkapkan kenyataan karena ceritanya hampir selalu diragukan. Ia juga jenuh karena mendapatkan pertanyaan-pertanyaan yang sama dan cenderung menyudutkannya, mulai dari polisi, pengacaranya, pengacara pelaku, jaksa, hakim, wartawan, dan yang pihak lainnya. Harper pun memilih untuk diam. Hal ini membuktikan kebenaran dalam gagasan Bhasin melalui Kurnianto (2016: 89) bahwa sistem patriarki menegaskan ideologi bahwa laki-laki lebih superior sehingga perempuan sudah seharusnya dikontrol dan dijadikan patriarki. Perempuan juga didefinisikan sebagai makhluk yang pasif dan reseptif.

Dengan mengutip media yang ditampilkan dalam novel Scars, pelaku kekerasan seksual diterangkan sebagai "mahasiswa dari Universitas Stanford", "Scott Gideon" (empat kali disebutkan), "20 tahun", "diduga tengah memperkosa" (hal. 7), "melarikan diri", "diringkus", "tim pengacara", "Scott Gideon" (tiga kali disebutkan), "mahasiswa universitas prestisius Stanford", "masuk dengan beasiswa penuh di bidang olahraga", "lulus dengan predikat valedictorian", "menyandang posisi penting", dan "tim rugbi" (hal. 8). Kutipan-kutipan tersebut memperlihatkan bagaimana nama tokoh pelaku 
pemerkosaan tidak ditutupi atau dianonimkan seperti korbannya. Hal ini dapat diasumsikan sebagai bentuk 'keberanian' dan 'kesiapan' pihak Scott Gideon untuk menghadapi tuntutan atas peristiwa tersebut. Prestasi laki-laki itu sebagai atlet kampus dan beasiswa yang didapatkannya seperti diglorifikasi untuk memperlihatkan betapa ia adalah sosok yang maskulin, populer, pandai, dan patut dibela.

Ini juga pembelaan yang mereka gunakan semasa persidangan berlanjut. "Dia murid terbaik di sekolahnya, atlet beasiswa dengan segudang prestasi. Terlalu banyak yang harus dipertaruhkan dengan melakukan hal-hal bodoh yang berakibat fatal. Kalian berdua sama-sama mabuk dan tidak ada yang bisa membuktikan kalau terjadi sesuatu yang tak diinginkan. (Efendi, 2020: 98)

Kutipan tersebut membuktikan bahwa dari sudut pandang pelaku dan para simpatisannya, kekerasan seksual yang merupakan tindak kejahatan tidak dianggap penting dan cenderung dikecilkan artinya sebagai "hal-hal bodoh" yang secara implisit dapat dilakukan oleh semua orang. Terlebih lagi, ada alibi atas perbuatan itu yaitu kondisi "mabuk" dan "tidak sadar" yang di mata hukum membuat pelaku dianggap tidak sedang menguasai pikirannya sehingga tidak dapat bertanggung jawab atas perilakunya. Adapun pandangan yang menganggap bahwa kejadian pemerkosaan sekedar 'hubungan satu malam yang mengecewakan' disebut Millet, melalui Humm (2007: 388-389), sebagai erotisisme yang diberlakukan untuk menurunkan martabat perempuan.

Pembelaan pada Scott Gideon juga dilakukan Clay, teman Adam, yang membuat mereka kemudian berkelahi. Sebagai kekasih Harper, Adam tidak dapat menerima sikap temannya itu. 'Siapa yang tahu apa yang sebenarnya terjadi hari itu'. Dia bilang, mungkin pria yang malang itu justru dihukum untuk sesuatu yang tak dia lakukan ... (hal. 220). Clay menyebut pelaku pemerkosaan sebagai "pria yang malang", yang memperlihatkan keberpihakannya pada Scott. Hal ini memperlihatkan adanya paradigma bahwa Scottlah yang telah dirugikan oleh Harper dengan tuduhannya.

Peristiwa pemerkosaan yang dialami tokoh Harper selain termasuk kekerasan psikologis karena mengganggu kondisi mentalnya, juga merupakan kekerasan fisik karena merusak virginitas dari remaja perempuan itu. Dworkin melalui Humm (2007: 389) menegaskan bahwa pemerkosaan adalah tindakan seksual dan sekaligus tindakan agresi, pemerkosaan juga merupakan pelanggaran atas hak milik dan kejahatan politik. "Sumber menyebutkan adanya darah di tempat kejadian, yang kini telah diamankan polisi setempat untuk investigasi lebih lanjut" (Efendi, 2020: 8). Darah yang dimaksud dalam kutipan tersebut patut diduga merupakan darah Harper saat dinodai penyerangnya.

Sebagai perempuan Barat yang hidup di tengah modernitas, Harper ternyata dibesarkan dengan latar budaya yang konservatif. Sebagaimana dijelaskan Permatasari (2017: 94), dalam perspektif tersebut, virginitas masih dimaknai perempuan sebagai bentuk penghargaan atas tubuhnya. Dengan mengapresiasi virginitasnya, perempuan dianggap telah berkuasa terhadap kepemilikan tubuhnya dalam budaya dan hukum patriarki. Oleh karena itu, pelanggaran atas hak kepemilikan tubuh oleh laki-laki melalui kekerasan seksual dapat dinilai sebagai tindakan opresif dan sewenang-wenang seperti 
yang dipertanyakan oleh Harper, "Bagian mana dari memerkosa seorang perempuan mabuk yang tidak berdaya yang bisa disebut berkelakuan baik?” (hal. 206).

Novel Scars seperti merupakan rekonstruksi dari kisah nyata pada tahun 2015 yang menimpa remaja perempuan bernama Chanel Miller. Dalam kasusnya, laki-laki pelaku pemerkosaan hanya divonis enam bulan dari keputusan juri yang menghendaki sepuluh tahun masa tahanan. Namun, Scott Gideon seperti juga Brock Allen Tunner, sang pelaku pemerkosaan yang nyata, ternyata menjalani tiga bulan masa penjara saja dan kemudian dibebaskan dengan alasan akan berbuat baik setelah kejadian itu. "Monster dalam mimpi burukku kini mendekam di balikjeruji besi, menjalani hukuman yang terlalu ringan untuk apa yang sudah dia lakukan padaku" (hal. 11). Meskipun pada akhirnya, dikisahkan bahwa Scott Gideon mendapatkan pengawasan khusus dan mendapat sanksi sosial, tetap saja hukuman yang dijalaninya dianggap oleh sang korban tidak setimpal. Ketidakajekan standar dalam menjatuhkan hukuman pada pelaku ini menjelaskan gagasan Rich yang dikutip Humm (2007: 389-390), bahwa pemerkosaan bukan peristiwa individual yang berdiri sendiri melainkan gejala penyakit dalam struktur kekuasaan dan ketidakberdayaan yang meluas di dalam masyarakat.

Ia wajib mendaftar sebagai pelaku tindak kejahatan seksual dan menjalani rehabilitasi. [...] menjauhi alkohol dan narkoba selama tiga bulan masa percobaannya. Universitas Stanford juga telah memberikan pernyataan terpisah bahwa Scott Gideon sudah dikeluarkan dari program beasiswa dan daftar mahasiswa kampus tersebut. (Efendi, 2020: 209).

Novel Scars menunjukkan bahwa kekerasan seksual berupa pemerkosaan dapat menimpa siapa pun dan dilakukan siapa pun. Sebagaimana dinyatakan Humm (2007: 388), pemerkosaan adalah bentuk pemaksaan sosial yang paling busuk yang membuat semua perempuan harus mengingat kondisi mereka yang rentan. Situasi ini diperlihatkan bahwa selain Harper, ada perempuan korban kekerasan seksual lain yaitu tokoh Jordan O'Malleys, pemilik penampungan hewan yang mengalami pelecehan semasa remaja oleh orang tua angkatnya. Selain itu, juga ada Brooke, perempuan New York yang ditampilkan pada bagian akhir novel tersebut sebagai korban pemerkosaan kekasihnya, sehingga mendapat pendampingan hukum dari Harper. Kebangkitan para tokoh perempuan yang pernah mengalami masa-masa sulit itu tidak berjalan mudah, namun berkat kemampuan resilien, mereka dapat keluar dari situasi depresif tersebut.

\section{Resiliensi Perempuan menghadapi Trauma Akibat Kekerasan Seksual}

Dalam perspektif Sameroff dkk (2003), setidaknya ada dua faktor penentu perilaku resilien. Yang pertama adalah adanya ancaman, dan yang kedua adalah kriteria sebagai penentu hasil dari tindakan untuk bangkit dari keterpurukan. Penentu pertama dari resiliensi pada tokoh Harper adalah risiko atau kesulitan yang dihadapinya sebagai korban pemerkosaan. Remaja perempuan itu mengalami hambatan-hambatan untuk dapat bertahan dan sembuh dari penderitaannya. Terkadang ia dipandang rendah dan dianggap sebagai sangat rapuh sehingga orang-orang di sekitarnya bersikap sangat 'hati-hati' saat bersamanya. Ke mana pun ia pergi, trauma selalu mengikutinya. Ia menjadi waspada dan 
penuh ketakutan bila Scott Gideon, si pemerkosa, berada di dekatnya dan akan memaksakan kehendak lagi padanya. Remaja perempuan itu pun menjadi sangat paranoid dan terus berprasangka buruk pada orang di dekatnya.

Meskipun sulit, Harper berusaha menyembuhkan diri dengan cara berbicara pada dirinya sendiri. Dalam teks, hal ini diperlihatkan melalui tulisan berkarakter italik, seperti "Berhentilah berpikir yang tidak-tidak, Harper. Kau kelewat paranoid" (hal. 12). Selain berupaya menguatkan dirinya sendiri, usaha yang dilakukan Harper adalah mengikuti sesi konseling dengan Dokter Lewis. Terapi-terapi itu memang tidak segera memberikan hasil yang maksimal, karena perempuan itu cenderung menutup diri dan menganggap akan lebih aman jika bersikap demikian. Namun, kemudian ia memberanikan diri kembali ke sekolah dan bersosialisasi kembali seperti dulu.

"Aku ingin terus hidup untuk melihat mereka tersenyum sekali lagi. Aku ingin hidup untuk melihat pria itu dihukum seberat-beratnya, untuk apa yang telah diambilnya dariku. Aku ingin hidup untuk memberikan diriku sendiri kesempatan kedua, meski terkadang bertahan hidup terasa sangat sulit.” (Efendi, 2020: 173)

Resiliensi, sebagaimana dijelaskan Masten melalui Zahra (2021: 121), merupakan kapasitas sistem dinamis untuk berhasil beradaptasi dengan gangguan. Kutipan tersebut memperlihatkan bagaimana bantuan orang di sekitarnya, seperti guru konselor, membuat Harper bangkit dan mengisi harinya dengan menjadi sukarelawan di tempat penampungan hewan liar milik Jordan. Kerja paruh waktunya itu memberinya banyak pelajaran dan pengalaman tentang hidup. Dengan berkegiatan seperti itu, ia pun dapat sedikit melupakan kejadian pemerkosaan yang pernah menimpanya dan seluruh dampak dari peristiwa yang mengubahnya itu.

Dalam foto itu, aku tengah memeluk lutut sembari memperhatikan sekelompok anak anjing yang terluka sedang makan dengan lahap, sorot mataku lembut. Aku tidak tahu kapan foto itu diambil dan siapa yang memotretnya, tapi aku tahu mengapa Jordan mengirimkannya kepadaku. Dia ingin aku ingat, hal-hal yang membuat kita jatuh sering kali juga merupakan hal-hal yang mampu membuat kita kuat. (Efendi, 2020: 278)

Dukungan dari support system-nya, yaitu keluarga (ayahnya dan Avery), sahabat (Rachel), dan pacar (Adam) menjadi penyemangat untuk sembuh dan kembali menjadi Harper yang dulu lagi. Harper menganggap bahwa merekalah penyelamatnya, terutama ayahnya, yang sejak kematian ibu mereka mengurus si kembar dengan sebaik-baiknya. Ia selalu ada untuk masa senang maupun masa sulit anak-anaknya.

Dad yang memasak untuk kami. Dia yang siap dengan panekuk setiap pagi, membuat wajah-wajah tersenyum dengan saus bluberi walau tak ada dari kami yang ingin tersenyum. [...] Dia yang menenangkanku pada minggu-minggu pertama aku terbangun karena mimpi buruk, menjerit-jerit bagai kesetanan, dan meledak dalam kemarahan. Dia seperti batu karang yang tak tergoyahkan, satusatunya yang bis kuandalkan ketika duniaku runtuh. (Efendi, 2020: 167) 
Bagaimanapun besarnya dukungan dari lingkungan sekitar, Harper memahami bahwa ia harus menguatkan dirinya sendiri terlebih dahulu. Setelah menjadi lebih stabil, ia pun tidak lagi segan untuk berbagi pengalaman buruknya dalam pekan anti kekerasan seksual saat perpisahan sekolah.

“Apa yang terjadi tidak akan berangsur-angsur hilang dengan menguburnya dalam-dalam. Satu-satunya cara untuk pulih adalah berdamai dengan trauma itu sendiri, juga berhenti mengasosiasikan aspek-aspek yang terlibat dengan perasaan negatif." (Efendi, 2020: 78)

Bentuk resiliensi Harper yang lainnya adalah melanjutkan hidup sesuai dengan keinginannya. Ia melanjutkan studi di New York University, tempat yang jauh dari kota kecil Bodega Bay yang telah memberinya kenangan buruk. Ia pun membantu memberi pendampingan hukum pada para penyintas kekerasan seksual sekaligus memulihkan dirinya sendiri. Harper menerapkan pesan dari Miss Yarley, konselornya saat SMA, bahwa "penderita trauma tidak selamanya adalah korban. Mereka juga bisa menjadi orang-orang yang bangkit dan lebih kuat daripada sebelumnya." (hal. 35). Keberhasilan perempuan ini dalam mengatasi trauma dan melakukan 'bounce back' bangkit kembali memperlihatkan faktor resilien kedua yang disebutkan oleh Sameroff dkk (2003).

Keterpurukan dan depresi yang sempat dialami oleh ayah dan adik kembar Harper pun dapat diatasi melalui perilaku positif dan saling mendukung. Menurut Walsh (2003), kemampuan keluarga sebagai sebuah sistem yang dapat bertahan dan pulih kembali dari masa sulit, tepatnya setelah peristiwa pemerkosaan terhadap Harper, disebut dengan resiliensi keluarga. Sistem keyakinan, pola organisasi, dan pola komunikasi merupakan faktor-faktor penting untuk bersama-sama bangkit kembali dari situasi yang buruk sebagaimana ditunjukkan oleh Harper, Avery, dan ayah mereka.

Pada akhirnya, berkat resiliensi dan keteguhan hati sebagai seorang penyintas, Harper dapat menerima kondisinya dan menjadi inspirasi bagi perempuan-perempuan di tempat lain yang tengah mengalami dan merasakan hal serupa. "Karena pada akhirnya, satu-satunya yang bisa kita lakukan untuk diri sendiri hanyalah berdamai dengan apa yang terjadi dan melanjutkan hidup." (hal. 218). Hal ini sejalan dengan judul novel Scars and other beautiful things, yang memperlihatkan bahwa Harper telah menerima "her scars" lukanya sebagai hal penting yang membawa dirinya pada keadaan yang jauh lebih baik.

\section{SIMPULAN}

Penelitian ini memperlihatkan bahwa kekerasan seksual merupakan bentuk ekspresi yang salah dari maskulinitas. Kekerasan seksual juga berkaitan dengan stereotip tentang perempuan sebagai pihak korban yang justru disalahkan, karena dianggap berpakaian terbuka atau berperilaku ramah sehingga mengundang hasrat laki-laki. Tokoh Harper pun memperlihatkan resiliensi untuk keluar dari situasi traumatis yang sangat tidak menguntungkannya, dengan bantuan dari sistem pendukungnya yaitu keluarga, sahabat, 
dan pacarnya. Melalui novel Scars, terungkap kritik pengarang mengenai kasus kekerasan seksual yang kerap menimpa perempuan (maupun laki-laki). Kenyataan memperlihatkan bahwa pelakunya sering tidak mendapat hukuman yang setimpal. Yang sering terjadi, korban yang seharusnya dilindungi dan mendapatkan hak konseling yang layak malah dikriminalisasi.

Kekerasan seksual sebenarnya bukan merupakan tema yang cocok untuk genre metropop yang pada umumnya mengisahkan permasalahan percintaan antar tokoh dalam ruang urban. Namun, topik tersebut menjadi relevan dengan penggambaran kejadiankejadian yang memang secara faktual menjadi problem bagi masyarakat kota, terutama ketika perempuan yang menempati posisi sebagai korban tidak mendapatkan keadilan.

\section{REFERENSI}

Appleton, C. M. K. (2018). Filling the Silence: Giving Voice to Gender Violence in Una's Graphic Novel Becoming Unbecoming. International Research in Children's Literature, 11(1), 47-64. doi:10.3366/ircl.2018.0253

Astuti, N. M. I. P. (2021). Perilaku Subordinasi, Kekerasan, dan Penjinakan (Cooptation) Tokoh Perempuan dalam Novel Putri I Karya Putu Wijaya: Kajian Feminisme. Jurnal Mimbar Ilmu, 26(1), 1-9.

Eddyono, S. W. (2014). Hak Asasi Perempuan dan Konvensi CEDAW. Referensi HAM. https://referensi.elsam.or.id/2014/09/hak-asasi-perempuan-dan-konvensi-cedaw/

Efendi, W. (2020). Scars and Other Beautiful Things. Jakarta: PT Gramedia Pustaka Utama.

Figes, E. (1986). Patriarchal Attitudes. London: Macmillan Education.

Fitri, C. N. (2018). Analisis Unsur Kekerasan dalam Novel-novel Karya Arafat Nur. Master Bahasa, 6(3), 213-225.

Hardiyanto, F. (2008). Kekerasan terhadap Perempuan yang dialami Tokoh Mira dalam Novel Wajah Sebuah Vagina karya Naning Pranoto Sebuah Kajian Sosiologi Sastra. (Skripsi), Universitas Sanata Dharma, Yogyakarta.

Haryatmoko. (2010). Dominasi Penuh Muslihat Akar Kekerasan dan Diskriminasi. Jakarta: Gramedia Pustaka Utama.

Hd. (2016). Korban Pemerkosaan di Stanford Jadi Simbol Keberanian. VOA Indonesia. https://www.voaindonesia.com/a/korban-pemerkosaan-di-stanford-jadi-simbolkuat/3368530.html

Humm, M. (2007). Ensiklopedia Feminisme (M. Rahayu, Trans.). Yogyakarta: Fajar Pustaka Baru.

Index-Report, G. $\quad$ E. (2013). Vilnius. Retrieved from http://eige.europa.eu/sites/default/files/documents/Gender-Equality-IndexReport.pdf

Intan, T., Trisna Gumilar. (2020). Perempuan Bersampur Merah Karya Intan Andaru: Resiliensi Perempuan Terhadap Stigma dan Trauma. Linguista: Jurnal Ilmiah Bahasa, Sastra, dan Pembelajarannya, 4(1), 9-21.

Kanserina, P. D. (2011). Kekerasan Seksual pada Tokoh Utama Grace Adams dalam Novel Malice Karya Danielle Steel. Lensa, 1(2), 141-152.

Kurnianto, E. A. (2016). Resistensi Perempuan terhadap Wacana Ratu Rumah Tangga dalam Cerpen Intan Paramaditha. Atavisme, 19(1), 88-101. 
Mayroh, I. I. (2019). Kekerasan terhadap Perempuan dalam Novel Tuhan Izinkan Aku Menjadi Pelacur! Karya Muhidin M. Dahlan. Paper presented at the SENASBASA (Seminar Nasional Bahasa dan Sastra).

Milestone, K., \& Meyer, A. (2012). Gender and Popular Culture. Cambridge, UK: Polity. Nurhadi. (tanpa tahun). Latar Luar Negeri Karya-karya Fiksi Indonesia. 1-10.

Permatasari, D. B. A. (2017). Resistensi Tokoh-tokoh Perempuan terhadap Patriarki dalam Novel Garis Perempuan Karya Sanie B. Kuncoro. Jentera: Jurnal Kajian Sastra, 6(2), 94-109.

Prasetyo, Y. H. (2017). Kekerasan terhadap Tokoh Perempuan dalam Novel Seperti Dendam Rindu Harus Dibayar Tuntas dan Lelaki Harimau Karya Eka Kurniawan. Seloka, 6(2), 152-160.

Priyatna, A. (2018). Kajian Budaya Feminis Tubuh, Sastra, dan Budaya Pop. Yogyakarta: Arti Bumi Intaran.

Priyatna, A., Rasus Budhyono. (2020). Subjektivitas Perempuan dalam Dua Cerpen Karya Margaret Atwood dan Elizabeth Taylor. Aksara, 32(2), 191-208.

Sameroff, A., Gutman, L.M., \& Peck, S.C. (2003). Adaptation Among Youth Facing Multiple Risks: Prospective Research Findings. In Resilience And Vulnerability: Adaptation In The Context Of Childhood Adversities.

Sari, N. (2017). Kekerasan Perempuan dalam Novel Bak Rambut dibelah Tujuh Karya Muhammad Makhdlori. Jurnal Literasi, 1(2), 41-48.

Siebert, A. (2005). The Resiliency Advantages. San Fransisko: Berret-Koehler Publisher Inc.

Sunarti. (tanpa tahun). Perbandingan Novel Remember When Ketika Kau dan Aku Jatuh Cinta Karya Winna Efendi dengan Film Remember Karya Fajar Bustomi: Suatu Tinjauan Ekranisasi. 1-11.

Ungar, M. (2019). Designing Resilience Research: Using Multiple Methods To Investigate Risk Exposure, Promotive And Protective Processes, And Contextually Relevant Outcomes For Children And Youth. Child Abuse And Neglect. doi:Https://Doi.Org/10.1016/J.Chiabu.2019.104098

Walsh, F. (2003). Family resilience: A framework for clinical practice. Family Process, 42, 1-18. doi:https://doi.org/10.1111/j.1545-5300.2003.00001.x

Werdiningsih, Y. K. (2016). Kekerasan terhadap Tokoh Utama Perempuan dalam Novel Kinanti karya Margareth Widhy Pratiwi. Atavisme, 19(1), 102-115.

Winarno, E. (2003). Pengkajian Profil Tindak Kekerasan terhadap Perempuan dalam Keluarga. Jakarta: Departemen Sosial RI.

WRI. (2011). Training Metodologi Feminis untuk Pengembangan Pengetahuan Tingkat Dasar, Jakarta 24-27 Mei 2011. Retrieved from http://www.wri.or.id/67-capacitybuilding-id/training/89-training-metodologi-feminis-untuk-pengembanganpengetahuan-tingkat-dasar-24-27-mei-2011.html\#.W2RwL9IzbMw diakses 15 Juni 2020

Yulianto, A. (2018). Novel Cinta di dalam Gelas Karya Andrea Hirata: Sebuah Perjuangan Seorang Perempuan. Kelasa, 13(1), 1-12.

Zahra, F. H., Nabilah, H. R., \& Wedyaswari, M. (2021). Resiliensi pada Mahasiswa Bidikmisi Tingkat Pertama Universitas Padjadjaran. Journal An-Nafs Kajian Penelitian Psikologi, 6(1), 120-134. 